\title{
Ramsay Hunt syndrome revisited-emphasis on Ramsay Hunt syndrome with multiple cranial nerve involvement
}

\author{
Eva Rye Rasmussen ${ }^{1 *}$, Eva Lykke ${ }^{2}$, Jan Gren Toft ${ }^{3}$ and Kristianna Mey ${ }^{4}$ \\ *Correspondence: eva.rye.rasmussen@dadlnet.dk \\ CrossMark \\ $\leftarrow$ Click for updates

\begin{abstract}
'Department of Otolaryngology-head and neck surgery, Lykkebaekvej 1, 4600 Koege, Denmark. ${ }^{2}$ Department of Otolaryngology-head and neck surgery, Blegdamsvej 9B, 2100 Copenhagen East, Denmark. ${ }^{3}$ Private practice Ear, nose and throat diseases Strandgade 41, 4800 Nykoebing Falster, Denmark. ${ }^{4}$ Department of Otorhinolaryngology and audiology, Copenhagen University Hospital Rigshospitalet/Gentofte, Niels Andersens vej 65, 2900 Hellerup, Denmark.
\end{abstract}

\begin{abstract}
Introduction: The Ramsay Hunt syndrome is characterized by herpetic lesions combined with peripheral facial nerve palsy. The disease is caused by a reactivation of the varicella zoster virus and can be deceiving since the herpetic lesions are not always present (zoster sine herpete) and might mimic other severe neurological illnesses. This article reviews the various forms of Ramsay Hunt syndrome and how they can give rise to diagnostic and therapeutic challenges.

Material and method: Studies on the assessment and treatment of Ramsay Hunt syndrome were found by conducting a thorough literature search in PubMed, Medline, The Cochrane Library database and Google Scholar using the search words «varicella», «zoster», «ramsay hunt», «oticus», «cranial nerve», «facial nerve» and combinations thereof. The bibliographies of substantial articles were subsequently assessed.

Results: About $12 \%$ of all peripheral facial nerve palsies are caused by varicella zoster virus. In more than $50 \%$ pain is the initial symptom making the diagnosis difficult. Female gender, and in general age above 50 years, renders patients more susceptible to Ramsay Hunt syndrome. The main prognostic factor is the severity of the initial symptoms. The occurrence rate of associated cranial polyneuropathy has been reported to be $1.8-3.2 \%$ and cranial nerves VII, VIII, IX are the ones most commonly affected. The full recovery rate is reported to be as low as $27.3 \%$ when multiple cranial nerves are involved. Combination therapy comprising of antiviral drugs and corticosteroids is recommened and should be initiated within 72 hours. Vaccination against varicella zoster virus is an interesting new development that might reduce the incidence of varicella zoster virus associated disease altogether.

Conclusion: Ramsay Hunt syndrome is a difficult and severe diagnosis with a low full recovery rate. Extensive randomized trials are urgently needed to verify the optimal treatment and the efficacy of varicella zoster virus vaccine in both naïve and herpes zoster patients.
\end{abstract}

Keywords: Ramsay Hunt syndrome, facial paralysis, herpes zoster, herpes zoster oticus, cranial nerve diseases

\section{Introduction}

James Ramsay Hunt was an American physician and scientist who, in the $20^{\text {th }}$ century, described a series of cases suffering from herpetic lesions in the oral cavity or external ear, combined with facial palsy and often accompanied by other neurological disturbances [1]. Since those days, the Ramsay Hunt syndrome (RHS) has been investigated thoroughly and different classifications and definitions of the disease have been proposed [1,2]; however no single definition has been agreed upon representing a 'golden standard'. Hunt himself classified the disease into four subgroups according to the extent of the pathological processes taking place in the geniculate ganglion (Table 1) [3]. The disease is caused by a reactivation of the varicella zoster virus (VZV) of the alpha herpes family; the symptoms are deceptive since the herpetic lesions are not always present (zoster sine herpete) and might mimic several other neurologic illnesses such as cerebral insults, Lyme disease and meningitis. This article reviews the various forms of RHS in adult immunocompetent patients as they present themselves to a broad selection of medical specialties, leading to diagnostic and therapeutic challenges.

\section{Method}

In order to evaluate earlier work with regard to the assessment and treatment of RHS, a thorough literature search was conducted in PubMed, Medline, The Cochrane Library database and Google Scholar using the search words «varicella», «zoster», «ramsay hunt», «oticus», "cranial nerve», «facial nerve» and combinations thereof. A PubMed search exclusively on «Ramsay Hunt» alone produced 431 hits; the search for "zoster oticus» produced 407 hits, thus proving the need for a more restrictive search strategy. Only articles in English published 
Rasmussen et al. Virology Discovery 2014,

Table 1. Original classification of Ramsay Hunt syndrome.

\begin{tabular}{l}
\hline Hunt's classification of 'his' syndrome \\
\hline 1. Disease affecting the sensory portion of the seventh cranial nerve \\
2. Disease involving the sensory and motor divisions of the seventh cranial \\
nerve \\
3. Disease affecting the sensory and motor divisions of the seventh cranial \\
nerve with auditory \\
symptoms \\
4. Disease affecting the sensory and motor divisions of the seventh cranial \\
nerve with both auditory and vestibular symptoms
\end{tabular}

since the year 2003 were included in the subsequent search; resulting in 82 hits. In order to find the original articles, the bibliographies of selected reviews were examined, expanding both the time frame and the allowed languages (English, German, Norwegian and Danish). Articles reporting solely on immune-incompetent patients were excluded. Patients suffering from diabetes mellitus were regarded as immunecompetent in this review. In some articles both immunecompetent and-incompetent patients were reported on, but for our purposes the immune-incompetent patients has been excluded. Furthermore the authors prioritized original research rather than reviews and reference articles. The search was concluded on $11^{\text {th }}$ of April 2013.

\section{Epidemiology}

\section{General data and incidence}

About $12 \%$ of all peripheral facial nerve palsies are caused by VZV [4]. Female gender, and in general age above 50 years, renders patients more susceptible to Ramsay Hunt syndrome $[5,6]$. Epidemiological data is summarized in Table 2 [6-8]. The reason for female predisposition to Ramsay Hunt syndrome is unknown, but the incidence of i.e., herpes simplex infection is also higher in females [9]. Regarding the frequency of RHS and cranial nerve involvement the statements in the literature diverge substantially. This might be due to the fact that some neurological deficits are difficult to assess, especially for the untrained eye. Since RHS is a relatively rare condition, not much epidemiological data is available on which cranial nerves are most commonly affected (Table 2). The occurrence rate of associated cranial polyneuropathy has been reported to be $1.8-3.2 \%[5,10,11]$. We gathered information on the involvement of cranial nerves from case reports published from 2003 to 2013 on immunocompetent adults (Table 3) [12-36].

\section{Prognosis}

The rate of full recovery was found to be $67.7 \%$ in RHS, but as low as $27.3 \%$ in patients with multiple cranial nerve involvement [10]. By contrast the data on recovery rate for individual cranial nerve involvements are not well established $[10,37]$. Post-herpetic neuralgia has been reported in as many as $50 \%$ of RHS patients [38]. The main prognostic factor seems to be the severity of the initial symptoms [39]. The US and Japan have now implemented varicella zoster vaccination
Table 2. Epidemiological data and prognosis $[5-7,10,33,38,40,42]$.

\begin{tabular}{|c|c|}
\hline Epidemiological Data & \\
\hline Incidence of HZ: & $\begin{array}{l}\text { HZ oticus: } 1 \% \text { of which } 96 \% \text { are associated } \\
\text { with peripheral facial nerve palsy }\end{array}$ \\
\hline & $\begin{array}{l}\mathrm{HZ} \text { in general: } 3.6 \text { per } 1000 \text { person-years, } \\
3 \% \text { with neurological complications }\end{array}$ \\
\hline $\begin{array}{l}\text { Incidence of involved } \\
\text { cranial nerves: }\end{array}$ & $\begin{array}{l}\text { HZ in general: Ophthalmic nerve affected } \\
\text { in } 10-29 \% \text { and facial nerve affected in } 1 \%\end{array}$ \\
\hline & $\begin{array}{l}\text { Associated cranial polyneuropathy: } \\
1.8-3.2 \%\end{array}$ \\
\hline & $\begin{array}{l}\text { VII, VIII, IX, X, V, III/XII } \\
\text { (incidence in decending order) }\end{array}$ \\
\hline & $\begin{array}{l}\text { VII, VIII, IX, V, X, VI, III, XI, IV, I/II/XII } \\
\text { (incidence in decending order) }\end{array}$ \\
\hline Prognosis/recovery: & $\begin{array}{l}\text { Full recovery: } 45.5 \% \text { of facial palsy and } \\
11.1 \% \text { of hearing loss }\end{array}$ \\
\hline & Full recovery: $46.7 \%$ of auditive symptoms \\
\hline & $\begin{array}{l}\text { Post-herpetic neuralgia in } 50 \% \text { of RHS } \\
\text { patients }\end{array}$ \\
\hline $\begin{array}{l}\text { Introduction of Varicella } \\
\text { Zoster vaccine }\end{array}$ & $\begin{array}{l}\text { Incidence of chickenpox, } \mathrm{HZ} \text { and sequelae } \\
\text { has declined }\end{array}$ \\
\hline & $\begin{array}{l}\text { Incidence of } \mathrm{HZ} \text { and post-herpetic pain } \\
\text { reduced with more than } 50 \%\end{array}$ \\
\hline & $\begin{array}{l}\text { Decreased incidence of HZ (and thus RHS) } \\
\text { in vaccinated populations }\end{array}$ \\
\hline
\end{tabular}

as part of their childrens vaccination programme and the incidence of chickenpox, herpes zoster (HZ) and sequelae has declined significantly $[\mathbf{6 , 4 0 , 4 1 ]}$. In persons 60 years of age or older, a reduction in incidence of $\mathrm{HZ}$ and post-herpetic pain of more than $50 \%$ has been shown to be achievable by vaccination [42].

\section{Pathophysiology \\ Natural history of VZV}

VZV, as does the herpes simplex virus, belongs to the family of alpha herpes viruses. It infects almost all humans in the form of chickenpox (varicella) and is spread by aerosolized respiratory droplets from infected individuals or by direct contact with a herpes zoster rash. The incubation period is 10-21 days and patients are contagious from 2 days before the rash appears until all elements have crusted, usually after 5-7 days. $\mathrm{HZ}$ is likewise contagious. VZV is a neurotrophic virus causing the classical variety of chickenpox in person's primary infected. Children usually exhibit milder symptoms than do adults, mainly manifested as an itching vesicular cutaneous rash; however severe and even fatal complications have been reported. Using the host's immune system, especially its T-cells, the virus is delivered to the skin and sensory nerves $[43,44]$. The virus is never cleared from the body but establishes a latent infection in the sensory ganglia and the facts that it does not spread is due to host's immune response and VZV antibodies. In the ganglia, the virus keeps itself hidden from the host's immune system $[\mathbf{4 5}, \mathbf{4 6}]$. Later in life the virus, like other herpes 
Rasmussen al. Virology Discovery 2014,

Table 3. A review of reported cases with immunocompetent adults diagnosed with Ramsay Hunt syndrome combined with multiple cranial nerve involvement from 2003-2013. Cranial nerve involvement in descending order of occurrence in parenthesis: $\mathrm{VII}(27), \mathrm{VIII}(26), \mathrm{X}(10), \mathrm{V}+\mathrm{IX}(8)$, $\mathrm{XII}(7), \mathrm{XI}+\mathrm{IV}(2)$ and $\mathrm{I}+\mathrm{III}+\mathrm{VI}(1)$ [12-36].

\begin{tabular}{|c|c|c|c|c|}
\hline Author \& publication year & $\begin{array}{l}\text { Number of } \\
\text { patients in study }\end{array}$ & Affected cranial nerves & Age In years & $\begin{array}{l}\text { Sex } \\
\text { Male/Female }\end{array}$ \\
\hline Kim D / 2008 & 1 & VII+VIII & 51 & $\mathrm{~F}$ \\
\hline Liao / 2011 & 1 & VII+VIII & 60 & M \\
\hline Bhagra / 2006 & 1 & VII+VIII & 64 & $\mathrm{~F}$ \\
\hline Gondivkar / 2010 & 1 & VII+VIII & 32 & M \\
\hline Galimi / 2011 & 1 & VII+VIII & 48 & M \\
\hline Van de Steene / 2004 & 2 & $\begin{array}{l}\text { VII+VIII } \\
\text { VII+VIII }\end{array}$ & $\begin{array}{l}64 \\
58\end{array}$ & $\begin{array}{l}\mathrm{F} \\
\mathrm{M}\end{array}$ \\
\hline Syal / 2004 & 1 & VII+VIII (bilateral) & 57 & M \\
\hline Hung / 2010 & 1 & V+VII+VIII & 77 & M \\
\hline Akyol / 2006 & 1 & V+VII+VIII & 61 & M \\
\hline $\operatorname{Lim} / 2011$ & 1 & V+VII+VIII & 50 & $\mathrm{~F}$ \\
\hline Padhiary / 2007 & 1 & VII+VIII+IX+X & 44 & M \\
\hline Wang / 2011 & 1 & $\mathrm{VII}+\mathrm{IX}+\mathrm{X}$ & 25 & M \\
\hline Saito / 2003 & 2 & $\begin{array}{l}\text { VII+VIII } \\
\text { VII+VIII+X }\end{array}$ & $\begin{array}{l}39 \\
66\end{array}$ & $\begin{array}{l}\mathrm{M} \\
\mathrm{F}\end{array}$ \\
\hline Kim JH / 2007 & 1 & VII+VIII+IX+X & 27 & M \\
\hline Shim / 2011 & 1 & VII+VIII+IX+X & 48 & M \\
\hline Espay / 2005 & 1 & VII+VIII+IX+XII & 83 & $\mathrm{~F}$ \\
\hline Izumi / 2007 & 1 & VII+VIII+XII & 72 & M \\
\hline Kim TU / 2012 & 1 & VII+VIII+IX+X+XII & 73 & $\mathrm{~F}$ \\
\hline Lauridsen / 2010 & 1 & $\mathrm{~V}+\mathrm{VII}+\mathrm{VIII}+\mathrm{X}+\mathrm{XII}$ & 56 & M \\
\hline Sun / 2011 & 1 & $\mathrm{~V}+\mathrm{VII}+\mathrm{VIII}+\mathrm{XII}$ & 62 & F \\
\hline Coleman / 2012 & 1 & $\mathrm{~V}+\mathrm{VII}+\mathrm{VIII}+\mathrm{X}$ & 81 & $\mathrm{~F}$ \\
\hline Godani / 2013 & 1 & IV + VII+ VIII & 69 & $\mathrm{~F}$ \\
\hline Nishioka / 2006 & 1 & $\begin{array}{l}\mathrm{III}+\mathrm{IV}+\mathrm{V}+\mathrm{VI}+\mathrm{VII}+\mathrm{VIII} \\
+\mathrm{IX}+\mathrm{X}+\mathrm{XI}+\mathrm{XII}\end{array}$ & 78 & M \\
\hline Morelli / 2008 & 1 & $\mathrm{~V}+\mathrm{VII}+\mathrm{VIII}+\mathrm{IX}+\mathrm{X}+\mathrm{XI}+\mathrm{XII}$ & 82 & M \\
\hline Sims / 2008 & 1 & I+VII+VIII & 81 & M \\
\hline
\end{tabular}

viruses, can become re-activated causing zoster (shingles) in all parts of the body [43]. The reason for the re-activation is believed to be caused by lessened immunity in the host over time $[\mathbf{4 2}, \mathbf{4 3}, \mathbf{4 7}]$. For the varicella zoster life-cycle see Figure $\mathbf{1}$.

\section{Localization of virus during zoster}

Different theories have been proposed as to where exactly VZV and associated inflammation are situated during a flare up of herpes zoster, but generally it is acknowledged, that the cause is ganglionitis. Theories involving viral spread due to vasculitis or perineuritis have also been considered $[34,48]$ and VZV has been electron microscopically observed in sensory nerves during $\mathrm{HZ}$ [49]. VZV is also found in the zoster elements during the vesicular phase [44]. Usually, no radiologic assessment is necessary, but Magnetic resonance imaging studies using gadolinium-diethylenetriamine penta-acetic acid often show enhancement of the intra-temporal segments of the facial nerve and internal auditive canal in patients with RHS [50].

\section{Clinical presentation}

RHS is a diverse and challenging disease, since it can be associated with neurological symptoms mimicking other diseases. Pathognomonic for the syndrome are peripheral facial nerve palsy and vesicular rash on the external ear, external auditory canal (which might only be visible by otoscopic assessment), and/or the mucosa of the ipsilateral part of the tongue or palate, usually accompanied by otalgia (Figures $2 \mathrm{a}$ and $\mathbf{2 b}$ ) $[1,7]$. By contrast there are also reports on facial nerve palsy and other cranial nerve palsies without herpetic lesions but with an increase of VZV antibodies, so called zoster sine herpete [51-53]. Pain in the affected area develops prior to a vesicular rash in $14-50 \%$ of VZV patients; the pain may mimic 


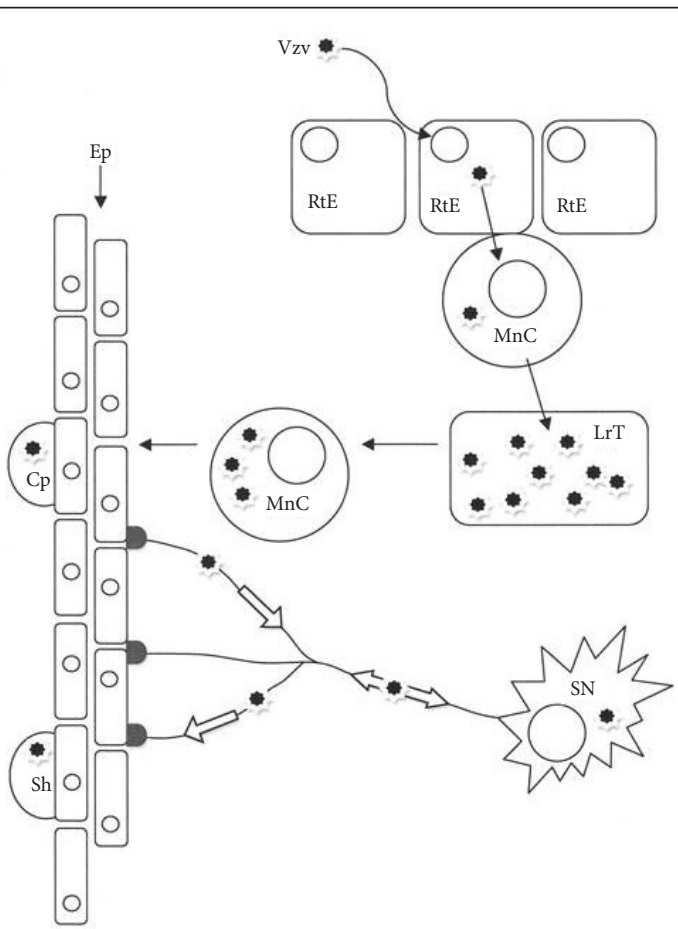

Figure 1. The Varicella Zoster Virus life cycle.

The varicella zoster virus (Vzv) enters the body through the respiratory tract epithelium (RtE). From here it infects the mononuclear cells (MnC), especially T-cells that carry the virus to the lymphoreticular tissues (LrT) where it replicates. In association with the $\mathrm{MnC}$ the virus enters the blood stream causing viremia and is seeded out to epithelial sites (Ep) creating chickenpox (Cp). The mucocutaneous lesions heal but the virus enters sensory nerve endings, is transported via the peripheral nerve to the sensory ganglia and a latent infection is established. Later in life a secondary infection can occur causing zoster or shingles (Sh) in the dermatome at the site of reactivation.

acute otitis and other ear diseases [6,39]. Furthermore, facial nerve palsy might develop several days before the rash in up to $20 \%$ of RHS patients $[11,39]$. More than half the patients have pain as their first symptom while as few as $2 \%$ have a rash as the initial symptom [39]. The usual RHS patient and the possible associated symptoms are described in Table 4.

\section{Diagnostic approach}

The RHS diagnosis is purely clinical, but in some cases a blood test for VZV antibodies may be useful. When other cranial nerves are affected, Magnetic resonance imaging may be necessary to exclude intracerebral pathology. The House Brachmann scale should be used to assess the facial nerve function initially and at every subsequent follow-up.

\section{Treatment}

\section{Antiviral drugs and/or corticosteroids}

RHS being a rare condition, only few studies on how to treat RHS have been carried out. Most of these studies are in favor of
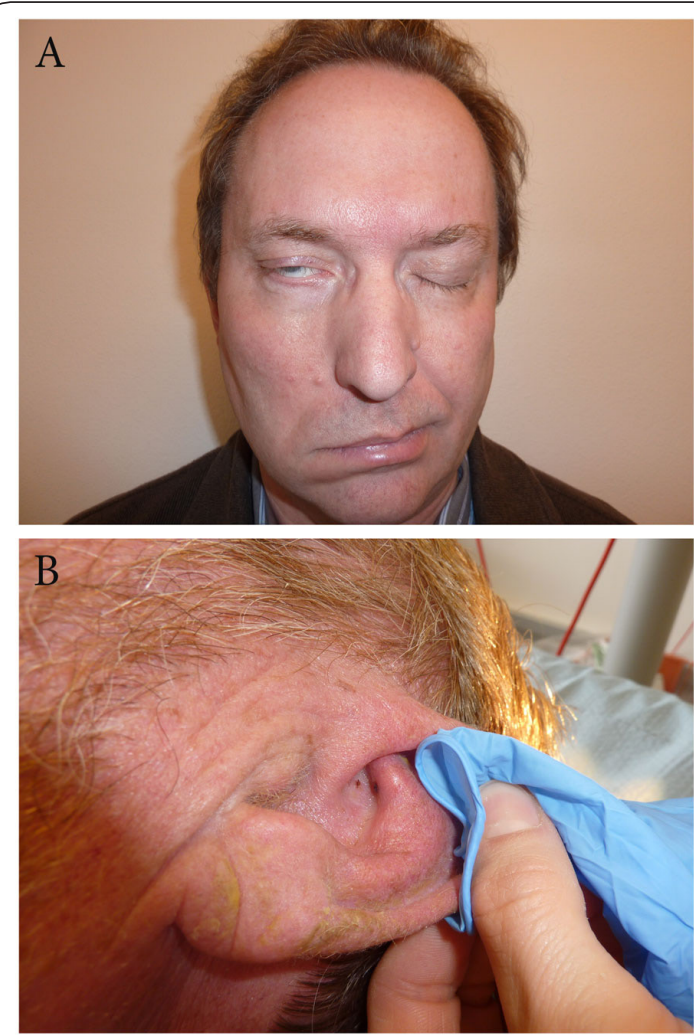

Figure 2. Peripheral facial nerve palsy and vesicular rash on the auricle. (A) Peripheral facial nerve palsy in a patient suffering from Ramsay Hunt syndrome. (B) Vesicular rash of the auricle in the remission phase.

Table 4. Pathognomonic and secondary symptoms of the Ramsay Hunt syndrome and related cranial nerves. Incidence in descending order.

\begin{tabular}{ll}
\hline Symptoms & Affected cranial nerves \\
\hline Pathognomonic symptoms (always present) & \\
\hline Herpetic vesicular rash & VII \\
Peripheral facial nerve palsy & VII \\
\hline Secondary symptoms (might be present) & \\
\hline Otalgia & V \\
Loss of hearing & VIII \\
Hyperacusis (due to palsy of chorda tympani) & VII \\
Vestibular symptoms (dizziness, nystagmus) & VIII \\
Taste disturbances, reduction of tear secretion & VII \\
Hoarseness (vocal cord palsy) & X \\
Weakness of the masseter and temporal muscles & V \\
Asymmetrical rise of the soft & IX \\
palate and/or uvula deviation & \\
Dyssensitivity of the face & V \\
Tongue deviation & XII \\
Dysphagia & IX, X \\
Ocular deviation & III,IV,VI \\
Dilated pupil & III \\
\hline
\end{tabular}


Rasmussen al. Virology Discovery 2014,

the use of antiviral drugs [54,55]. According to a Cochrane review, only one randomized controlled trial was performed including 15 patients; and no significant conclusions could be drawn as the study was deemed of low quality [56]. Other studies comprising small study populations have shown increased effects of acyclovir combined with corticosteroids compared to corticosteroids alone [39,57]. A main prognostic factor on outcome, with regard to medication, seems to be the time from debut of symptoms to initiation of treatment, whether consisting of combined acyclovir and corticosteroids or corticosteroids alone (Table 5) [58]. Some studies report on other treatment regimens like bed-rest, high protein, low sodium diet, peripheral vasodilators combined with acyclovir and corticosteroids, surgical decompression or anastomosis of the facial nerve but more extensive and randomized controlled studies are needed to define a 'golden standard' of RHS treatment $[\mathbf{1 0 , 5 9 ]}$. Until those studies are available, acyclovir in combination with corticosteroids are considered the correct treatment of RHS.

\section{Vaccination}

For persons of 60 years or older, vaccinating them against VZV effectively reduces the risk of $\mathrm{HZ}$ and post-herpetic pain whether or not these persons had had prior exposure to VZV. The pathophysiology is ascribed to the booster effect of the cell-mediated immunity against the dormant VZV (42). In children, the course of primary varicella zoster infection (chickenpox) in unvaccinated patients is markedly milder when vaccinated within 3 days from exposure $[\mathbf{6 0}, \mathbf{6 1}]$. Vaccinations are well tolerated and result in a 2.1 fold increase in VZV antibody level in patients with a positive history of $\mathrm{HZ}$ [62]. To the best of our knowledge, no substantial studies on the prognosis of the clinical outcome regarding vaccination or passive immunization of immunocompetent $\mathrm{HZ}$ or RHS patients have

Table 5. Recent recommendations in the treatment of Ramsay Hunt syndrome.

\begin{tabular}{|c|c|c|c|c|c|c|c|}
\hline Study/year & No. of Patients & $\begin{array}{l}\text { Combination } \\
\text { therapy }\end{array}$ & $\begin{array}{l}\text { Antiviral } \\
\text { treatment }\end{array}$ & $\begin{array}{l}\text { Corticosteroid } \\
\text { treatment }\end{array}$ & VZV Vaccine & $\begin{array}{l}\text { Initiation of treatment } \\
(\mathbf{d}=\text { days })\end{array}$ & $\begin{array}{l}\text { Comments / strong } \\
\text { points of study }\end{array}$ \\
\hline Coulson 2011 & 101 & YES & $\begin{array}{l}\text { From } 1998, \\
\text { famciclovir } \\
250 \mathrm{mg} \times 3 \text {, } \\
21 \mathrm{~d}\end{array}$ & $\begin{array}{l}1 \mathrm{mg} / \mathrm{kg} / \mathrm{d}, 14 \mathrm{~d} \text {, } \\
\text { decreased by } \\
10 \mathrm{mg} / \mathrm{d} \text { until } 0\end{array}$ & $\mathrm{NC}$ & $\begin{array}{l}\text { Early: }<5 \mathrm{~d} \\
\text { Late: }>5 \mathrm{~d}\end{array}$ & $\begin{array}{l}\text { Statistically significantly } \\
\text { better in } \\
\text { combination treatment } \\
\text { of early ACY+late COR }\end{array}$ \\
\hline Uri 2003 & 31 & YES & $\begin{array}{l}\text { ACY } 15 \mathrm{mg} / \\
\mathrm{kg} / \mathrm{d} \text { for } 7 \mathrm{~d}\end{array}$ & $\begin{array}{l}100 \mathrm{mg} \times 3 \text { for } \\
7 \mathrm{~d}\end{array}$ & $\mathrm{NC}$ & $\begin{array}{l}\text { Early } 1-3 d \\
\text { Late } 4-7 d\end{array}$ & $\begin{array}{l}\text { Recommends IV ACY } \\
\text { over oral } \\
\text { administration }\end{array}$ \\
\hline Kinishi 2001 & 91 & YES & $\begin{array}{l}\text { ACY } 4000 \\
\mathrm{mg} / \mathrm{d} \text { for } 7 \mathrm{~d}\end{array}$ & $\begin{array}{l}500 \rightarrow 100 \mathrm{mg} / \mathrm{d} \\
\text { decreased over } \\
7 \mathrm{~d}\end{array}$ & $\mathrm{NC}$ & $<7 \mathrm{~d}$ & $\begin{array}{l}\text { Assess ACY+COR on } \\
\text { facial nerve recovery } \\
\text { compared to COR } \\
\text { alone }\end{array}$ \\
\hline Hato 2000 & 52 & $\mathrm{NC}$ & $\mathrm{NC}$ & $\mathrm{NC}$ & YES & $\mathrm{NC}$ & $\begin{array}{l}\text { Reviews prognostic } \\
\text { factors for children with } \\
\text { RHS. None of the } 52 \\
\text { had VZV vaccine; the } \\
\text { incidence of RHS in } \\
\text { later years drops }\end{array}$ \\
\hline $\begin{array}{l}\text { Murakami } \\
1997\end{array}$ & 80 & YES & $\begin{array}{l}\text { ACY either } \\
250 \mathrm{mg} \times 3 \mathrm{IV} \\
\text { or } 800 \mathrm{mg} \times 5 \\
\text { orally for } 7 \mathrm{~d}\end{array}$ & $\begin{array}{l}1 \mathrm{mg} / \mathrm{kg} / \mathrm{d} \text { for } 5 \\
\mathrm{~d}, \text { decreased } 10 \\
\text { mg/d until } 0 \text {, } \\
\text { over } 10 \mathrm{~d}\end{array}$ & $\mathrm{NC}$ & $\begin{array}{l}\text { Early } 1-3 \mathrm{~d} \\
\text { Late }>7 \mathrm{~d}\end{array}$ & $\begin{array}{l}75 \% \text { recovered in } 1-3 \\
\mathrm{~d} \text { group } \\
30 \% \text { recovered in }>7 \mathrm{~d} \\
\text { group } \\
\text { Argues that onset of } \\
\text { treatment is essential }\end{array}$ \\
\hline De RU 2011 & NA & YES & NA & NA & $\mathrm{NC}$ & $\mathrm{NC}$ & $\begin{array}{l}\text { Meta-analysis of } \\
\text { reviews 1985-2010 - } \\
\text { strongly recommend } \\
\text { combination therapy }\end{array}$ \\
\hline $\begin{array}{l}\text { Uscategui } \\
2008 \text { (Oct) }\end{array}$ & NA & No evidence & NA & NA & Maybe & $<3 d$ & $\begin{array}{l}\text { Cochrane Review; finds } \\
\text { no quality RCT to } \\
\text { support the use of } \\
\text { antiviral compared to } \\
\text { the use of COR alone }\end{array}$ \\
\hline $\begin{array}{l}\text { Uscategui } \\
2008 \text { (June) }\end{array}$ & NA & No evidence & NA & NA & Maybe & $<3 d$ & $\begin{array}{l}\text { Cochrane Review; finds } \\
\text { no RCT at all to address } \\
\text { use of COR to support } \\
\text { antivirals }\end{array}$ \\
\hline
\end{tabular}

ACY: Acyclovir, COR: Corticosteroids, VZV: Varicella zoster virus, NC: Not commented, NA: Not applicable, RCT: randomized controlled trials, IV: Intravenously, d: days 
Rasmussen et al. Virology Discovery 2014,

been carried out. In theory, while vaccination of RHS patients at initial presentation could have some effect, this effect should be compared to the efficacy of corticosteroids and acyclovir.

\section{Conclusion}

RHS is a rare but severe condition defined by herpetic rash of the ear or the mucosa of the mouth and peripheral facial nerve palsy, most often combined with otalgia. The syndrome can be associated with several other cranial nerve symptoms mimicking intracerebral disease. The full recovery rate is reported to be as low as $27.3 \%$. Antiviral therapy combined with corticosteroids is recommended by most scientists in the field, although more randomized controlled trials are needed. Vaccination against VZV is an interesting new development that might reduce the incidence of VZV associated disease altogether. More studies regarding the potential efficacy of the VZV vaccine, given at the early sign of RHS, are urgently needed to combat this severe disease.

\section{List of abbreviations}

RHS: Ramsay Hunt syndrome

VZV: Varicella zoster virus

HZ: Herpes zoster

\section{Competing interests}

The authors declare that they have no competing interests.

Authors' contributions

\begin{tabular}{|l|c|c|c|c|}
\hline Authors' contributions & ERR & EL & JGT & KM \\
\hline Research concept and design & $\checkmark$ & -- & -- & $\checkmark$ \\
\hline Collection and/or assembly of data & $\checkmark$ & $\checkmark$ & $\checkmark$ & $\checkmark$ \\
\hline Data analysis and interpretation & $\checkmark$ & $\checkmark$ & -- & $\checkmark$ \\
\hline Writing the article & $\checkmark$ & $\checkmark$ & $\checkmark$ & $\checkmark$ \\
\hline Critical revision of the article & $\checkmark$ & -- & -- & $\checkmark$ \\
\hline Final approval of article & $\checkmark$ & $\checkmark$ & $\checkmark$ & $\checkmark$ \\
\hline
\end{tabular}

Publication history

Editor: Qiyi Tang, Ponce School of Medicine, USA.

EIC: Preet M. Chaudhary, University of Southern California Keck

School of Medicine, USA.

Received: 16-Apr-2014 Final Revised: 20-May-2014

Accepted: 21-May-2014 Published: 02-Jun-2014

\section{References}

1. Hunt J. On herpetic inflammations of the geniculate ganglion: a new syndrome and its complications. J Nerv Ment Dis. 1907; 34:73-96.

2. Robillard RB, Hilsinger RL, Jr. and Adour KK. Ramsay Hunt facial paralysis: clinical analyses of 185 patients. Otolaryngol Head Neck Surg. 1986; 95:292-7. | PubMed

3. Wackym PA. Molecular temporal bone pathology: II. Ramsay Hunt syndrome (herpes zoster oticus). Laryngoscope. 1997; 107:1165-75. I Article I PubMed

4. Peitersen E. Bell's palsy: the spontaneous course of $\mathbf{2 , 5 0 0}$ peripheral facial nerve palsies of different etiologies. Acta Otolaryngol Suppl. 2002; 4-30. | Article | PubMed

5. Kim YH, Chang MY, Jung HH, Park YS, Lee SH, Lee JH, Oh SH, Chang SO and Koo JW. Prognosis of Ramsay Hunt syndrome presenting as cranial polyneuropathy. Laryngoscope. 2010; 120:2270-6. I Article I PubMed

6. Yawn BP, Saddier P, Wollan PC, St Sauver JL, Kurland MJ and Sy LS. A population-based study of the incidence and complication rates of herpes zoster before zoster vaccine introduction. Mayo Clin Proc. 2007; 82:1341-9. | Article | PubMed

7. Wagner $G$, Klinge $H$ and Sachse MM. Ramsay Hunt syndrome. J Dtsch Dermatol Ges. 2012; 10:238-44. | Article | PubMed

8. Straube $A$ and Padovan CS. [Herpes zoster: follow-up, complications and therapy]. Nervenarzt. 1996; 67:623-9. | PubMed

9. Kortekangas-Savolainen O, Orhanen E, Puodinketo T and Vuorinen T. Epidemiology of genital herpes simplex virus type 1 and 2 infections in southwestern Finland during a 10-year period (2003-2012). Sex Transm Dis. 2014; 41:268-71. | Article | PubMed

10. Shim HJ, Jung H, Park DC, Lee JH and Yeo SG. Ramsay Hunt syndrome with multicranial nerve involvement. Acta Otolaryngol. 2011; 131:210-5. | Article | PubMed

11. Aviel A and Marshak G. Ramsay Hunt syndrome: a cranial polyneuropathy. Am J Otolaryngol. 1982; 3:61-6. | Article | PubMed

12. Kim D and Bhimani M. Ramsay Hunt syndrome presenting as simple otitis externa. CJEM. 2008; 10:247-50. | Article | PubMed

13. Liao WL, Sung PY, Chui WF and Chang TP. Vestibular rehabilitation therapy in a patient with chronic vestibulopathy of ramsay hunt syndrome. Am J Phys Med Rehabil. 2011; 90:851-5. | Article I PubMed

14. Bhagra A and Stead LG. Images in emergency medicine. Ramsay Hunt syndrome: a rare entity. Ann Emerg Med. 2006; 47:579, 584. | Article | PubMed

15. Gondivkar S, Parikh V and Parikh R. Herpes zoster oticus: A rare clinical entity. Contemp Clin Dent. 2010; 1:127-9. | Article | PubMed Abstract | PubMed Full Text

16. Galimi R. An unusual variant of Ramsay Hunt syndrome. $G$ Ital Dermatol Venereol. 2011; 146:307-8. | Article | PubMed

17. Van de Steene V, Kuhweide R, Vlaminck $S$ and Casselman J. Varicella zoster virus: beyond facial paralysis. Acta Otorhinolaryngol Belg. 2004; 58:61-6. | PubMed

18. Syal R, Tyagi I and Goyal A. Bilateral Ramsay Hunt syndrome in a diabetic patient. BMC Ear Nose Throat Disord. 2004; 4:3. | Article I PubMed Abstract | PubMed Full Text

19. Hung CW, Wang SJ, Chen SP, Lirng JF and Fuh JL. Trigeminal herpes zoster and Ramsay Hunt syndrome with a lesion in the spinal trigeminal nucleus and tract. I Neurol. 2010; 257:1045-6. | Article | PubMed

20. Akyol A, Kiylioglu N and Copcu E. An unusual cause of trismus: Ramsay Hunt syndrome. J Plast Reconstr Aesthet Surg. 2006; 59:206-7. | Article I PubMed

21. Lim Y, Tai ML, Tan LL and Sharma VK. Sudden-onset right facial drooping in a patient with Ramsay Hunt syndrome. Arch Neurol. 2011; 68:1198-9. | Article | PubMed

22. Padhiary KN, Mishra A and Routray P. Ramsay Hunt syndrome presenting as cranial polyneuropathy. J Assoc Physicians India. 2007; 55:308-9. I PubMed

23. Wang $F$ and Chen $X$. Case of Ramsay-Hunt syndrome associated with dysphagia. J Dermatol. 2011; 38:1195-7. | Article | PubMed

24. Saito S, Ochi K, Kobayashi T, Sugiura N, Komatsuzaki Y and Ohashi T. Vestibular-evoked myogenic potentials in two patients with Ramsay Hunt syndrome. Auris Nasus Larynx. 2003; 30 Suppl:S89-92. | Article | PubMed

25. Kim JH, Chung PW, Oh S, Hong SB, Chung CS, Jung CW, Kim ST, Hong SD and Seo DW. Ramsay Hunt syndrome complicated by a brainstem lesion. J Clin Virol. 2007; 39:322-5. | Article | PubMed

26. Shim JH, Park JW, Kwon BS, Ryu KH, Lee HJ, Lim WH, Lee JH and Park YG. Dysphagia in Ramsay Hunt's Syndrome - A Case Report. Ann Rehabil Med. 2011; 35:738-41. | Article | PubMed Abstract | PubMed Full Text

27. Espay AJ and Bull RL. Petrositis in Ramsay Hunt syndrome with multiple cranial neuropathies. Arch Neurol. 2005; 62:1774-5. | Article | PubMed

28. Izumi AK and Kitagawa K. Ramsay Hunt syndrome: a case report with cranial nerve XII involvement. J Am Acad Dermatol. 2007; 57:1102-3. | Article | PubMed

29. Kim TU, Kim SY, Kim JI and Lee SJ. Ramsay-Hunt syndrome accompanied 
Rasmussen al. Virology Discovery 2014,

by dysphagia: a videofluoroscopic swallowing study. Am J Phys Med Rehabil. 2013; 92:547-50. | Article | PubMed

30. Lauridsen AG and Mirz F. [Herpes zoster oticus with cranial nerve affection]. Ugeskr Laeger. 2010; 172:2849-51. | PubMed

31. Sun WL, Yan JL and Chen LL. Ramsay Hunt syndrome with unilateral polyneuropathy involving cranial nerves $\mathrm{V}, \mathrm{VII}, \mathrm{VIII}$, and $\mathrm{XII}$ in a diabetic patient. Quintessence Int. 2011; 42:873-7. | PubMed

32. Coleman C, Fozo M and Rubin A. Ramsay Hunt syndrome with severe dysphagia. J Voice. 2012; 26:e27-8. | Article | PubMed

33. Godani M, Giorli E, Traverso E, Beronio A, Capellini C and Del Sette M. Ramsay Hunt syndrome with trochlear nerve involvement and EEG abnormalities: multicranial neuritis or encephalitis? J Clin Virol. 2013; 56:277-9. | Article | PubMed

34. Nishioka K, Fujishima K, Kobayashi H, Mizuno Y and Okuma Y. An extremely unusual presentation of varicella zoster viral infection of cranial nerves mimicking Garcin syndrome. Clin Neurol Neurosurg. 2006; 108:772-4. | Article | PubMed

35. Morelli N, Mancuso M, Cafforio G, Gallerini S, Pittiglio L, Tonelli S, Pozzetti N, Benedetti L, Tavarelli C, Capellini C and Tartaglione A. Ramsay-Hunt syndrome complicated by unilateral multiple cranial nerve palsies. Neurol Sci. 2008; 29:497-8. | Article | PubMed

36. Sims JL and Zamir E. Acute retinal necrosis following steroid treatment for unrecognized Ramsay-Hunt syndrome. Clin Experiment Ophthalmol. 2008; 36:894-5. | Article | PubMed

37. Wayman DM, Pham HN, Byl FM and Adour KK. Audiological manifestations of Ramsay Hunt syndrome. J Laryngol Otol. 1990; 104:104-8. | Article | PubMed

38. Walther LE, Prosowsky K, Walther A and Gudziol H. [Herpes zoster oticus: symptom constellation and serological diagnosis]. Laryngorhinootologie. 2004; 83:355-62. | Article | PubMed

39. Coulson S, Croxson GR, Adams R and Oey V. Prognostic factors in herpes zoster oticus (ramsay hunt syndrome). Otol Neurotol. 2011; 32:1025-30. | Article | PubMed

40. Baxter R, Ray P, Tran TN, Black S, Shinefield HR, Coplan PM, Lewis E, Fireman $B$ and Saddier $P$. Long-term effectiveness of varicella vaccine: a 14-Year, prospective cohort study. Pediatrics. 2013; 131:e1389-96. | Article | PubMed

41. Hato N, Kisaki H, Honda N, Gyo K, Murakami S and Yanagihara N. Ramsay Hunt syndrome in children. Ann Neurol. 2000; 48:254-6. | Article | PubMed

42. Oxman MN, Levin MJ, Johnson GR, Schmader KE, Straus SE, Gelb LD, Arbeit RD, Simberkoff MS, Gershon AA and Davis LE et al. A vaccine to prevent herpes zoster and postherpetic neuralgia in older adults. $N$ Engl J Med. 2005; 352:2271-84. | Article | PubMed

43. Whitley $R$, Kimberlin $D$ and Prober $C$. Pathogenesis and disease, $p$. Chapter 32. In Arvin, A, Campadelli-Fiume, G, Mocarski, E, Moore, P, Roizman, B, Whitley, R, Yamanishi, K (eds.), Human herpesviruses: Biology, therapy, and immunoprophylaxis. Cambridge University Press, Cambridge. 2007.

44. Annunziato PW, Lungu O, Panagiotidis C, Zhang JH, Silvers DN, Gershon $\mathrm{AA}$ and Silverstein SJ. Varicella-zoster virus proteins in skin lesions: implications for a novel role of ORF29p in chickenpox. J Virol. 2000; 74:2005-10. | Article | PubMed Abstract | PubMed Full Text

45. Nakatani H, Yamakawa K, Hamada M, Takeda T, Kakigi A and Iwai $M$. Initial lesions in Bell's palsy and Ramsay-Hunt syndrome. ORL J Otorhinolaryngol Relat Spec. 2010; 71 Suppl 1:105-11. | Article | PubMed

46. Abendroth A, Lin I, Slobedman B, Ploegh H and Arvin AM. Varicellazoster virus retains major histocompatibility complex class I proteins in the Golgi compartment of infected cells. J Virol. 2001; 75:4878-88. | Article | PubMed Abstract | PubMed Full Text

47. Miller AE. Selective decline in cellular immune response to varicellazoster in the elderly. Neurology. 1980; 30:582-7. | Article | PubMed

48. Lapresle $J$ and Lasjaunias P. Cranial nerve ischaemic arterial syndromes. A review. Brain. 1986; 109 ( Pt 1):207-16. | Article | PubMed

49. Esiri MM and Tomlinson AH. Herpes Zoster. Demonstration of virus in trigeminal nerve and ganglion by immunofluorescence and electron microscopy. J Neurol Sci. 1972; 15:35-48. | Article | PubMed

50. Jonsson L, Tien R, Engstrom M and Thuomas KA. Gd-DPTA enhanced MRI in Bell's palsy and herpes zoster oticus: an overview and implications for future studies. Acta Otolaryngol. 1995; 115:577-84. | Article | PubMed

51. Murakami S, Honda N, Mizobuchi M, Nakashiro Y, Hato N and Gyo K. Rapid diagnosis of varicella zoster virus infection in acute facial palsy. Neurology. 1998; 51:1202-5. | Article | PubMed

52. Morgan $M$ and Nathwani $D$. Facial palsy and infection: the unfolding story. Clin Infect Dis. 1992; 14:263-71. | Article | PubMed

53. Gilden D, Cohrs RJ, Mahalingam R and Nagel MA. Neurological disease produced by varicella zoster virus reactivation without rash. Curr Top Microbiol Immunol. 2010; 342:243-53. | Article | PubMed Abstract | PubMed Full Text

54. Uri N, Greenberg E, Kitzes-Cohen R and Doweck I. Acyclovir in the treatment of Ramsay Hunt syndrome. Otolaryngol Head Neck Surg. 2003; 129:379-81. | Article | PubMed

55. de Ru JA and van Benthem PP. Combination therapy is preferable for patients with Ramsay Hunt syndrome. Otol Neurotol. 2011; 32:852-5. Article I PubMed

56. Uscategui T, Doree C, Chamberlain IJ and Burton MJ. Antiviral therapy for Ramsay Hunt syndrome (herpes zoster oticus with facial palsy) in adults. Cochrane Database Syst Rev. 2008; CD006851. | Article | PubMed

57. Kinishi M, Amatsu M, Mohri M, Saito M, Hasegawa T and Hasegawa S. Acyclovir improves recovery rate of facial nerve palsy in Ramsay Hunt syndrome. Auris Nasus Larynx. 2001; 28:223-6. | Article | PubMed

58. Murakami S, Hato N, Horiuchi J, Honda N, Gyo K and Yanagihara N. Treatment of Ramsay Hunt syndrome with acyclovir-prednisone: significance of early diagnosis and treatment. Ann Neurol. 1997; 41:3537. | Article | PubMed

59. Mehta RP. Surgical treatment of facial paralysis. Clin Exp Otorhinolaryngol. 2009; 2:1-5. | Article | PubMed Abstract | PubMed Full Text

60. Macartney K and McIntyre P. Vaccines for post-exposure prophylaxis against varicella (chickenpox) in children and adults. Cochrane Database Syst Rev. 2008; CD001833. | Article | PubMed

61. Ogilvie MM. Antiviral prophylaxis and treatment in chickenpox. A review prepared for the UK Advisory Group on Chickenpox on behalf of the British Society for the Study of Infection. J Infect. 1998; 36 Suppl 1:31-8. | Article | PubMed

62. Mills R, Tyring SK, Levin MJ, Parrino J, Li X, Coll KE, Stek JE, Schlienger $\mathrm{K}$, Chan IS and Silber JL. Safety, tolerability, and immunogenicity of zoster vaccine in subjects with a history of herpes zoster. Vaccine. 2010; 28:4204-9. | Article | PubMed

\section{Citation:}

Rasmussen ER, Lykke E, Toft JG and Mey K. Ramsay Hunt syndrome revisited-emphasis on Ramsay Hunt syndrome with multiple cranial nerve involvement. Virol Discov. 2014; 2:1. http://dx.doi.org/10.7243/2052-6202-2-1 